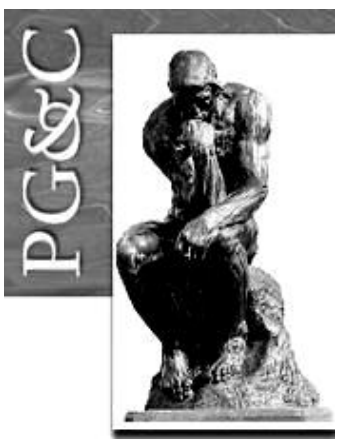

\title{
AFASTAMENTO DO TRABALHO: ANÁLISE DA PERCEPÇÃO DE GESTORES E REABILITADOS REINTEGRADOS À EMPRESA DE MANEIRA SUSTENTÁVEL
}

\author{
Sandra Regina Trevisan Gonçalves dos Santos \\ Mestre em Educação, Ambiente e Sociedade pelo Centro Universitário das \\ Faculdades Associadas de Ensino, Brasil. Professora da Universidade Brasil. \\ E-mail: sandracomunicacao@gmail.com \\ Luciel Henrique de Oliveira \\ Doutor em Administração pela Fundação Getúlio Vargas, Brasil. \\ Professor do Centro Universitário das Faculdades Associadas de Ensino, Brasil. \\ E-mail: luciel@uol.com.br
}

\begin{abstract}
Resumo
A reintegração dos trabalhadores afastados pelo Instituto Nacional de Seguridade Social (INSS) é um processo moroso. Melhorar a qualidade de vida e a produtividade no ambiente de trabalho são fatores primordiais para a empresa e para o trabalhador. Diante desta realidade do mundo do trabalho, este estudo tem como objetivo verificar a percepção de gestores e reabilitados reintegrados após afastamento por doença e/ou acidente de trabalho a empresa de maneira sustentável. A metodologia da pesquisa qualitativa baseia-se em estudos de casos múltiplos com a realização de entrevistas semiestruturadas aplicada a trabalhadores afastados por motivo de doença e/ou acidente de trabalho e seus gestores. O estudo tem como parâmetro a realidade de municípios pertencentes à Gerência Executiva do INSS de São João da Boa Vista, SP. A coleta de dados utiliza gravação em áudio, ficha de identificação e roteiro de entrevistas mediante autorização dos participantes e, submetido a análise de conteúdo, identifica duas categorias principais: o acidente de trabalho e/ou doença e o retorno ao trabalho. Conclui-se que os resultados da pesquisa indicam que, sentimentos e comportamentos despertados, poderão subsidiar um novo olhar do gestor para o reabilitado, levando-o a tratá-lo de maneira mais humana e respeitosa, esperando que o retorno do reabilitado para a empresa nem sempre configure apenas em permanecer numa mesma função, em ter o risco de experienciar novos acidentes ou ser desligado da empresa.
\end{abstract}

Palavras-chave: Reabilitação Profissional. Qualidade de Vida. Trabalho. Reintegração Profissional. Desenvolvimento Sustentável.

\section{DISMISSAL OF DISEASE AND OR ACCIDENT OF WORK: ANALYSIS OF PERCEPTION OF MANAGERS AND REHABILITATED REINTEGRATED TO COMPANY SUSTAINABLE}

\begin{abstract}
The reintegration of workers removed by the National Institute of Social Security (INSS) is a lengthy process. Improving the quality of life and productivity in the work environment are key factors for the company and for the worker. Given this reality of the world of work, this study aims to verify the perception of managers and rehabilitated reintegrated after sick leave and/or work accident in a sustainable way. The methodology of qualitative research is based on multiple case studies with semi-structured interviews applied to workers who are separated due to illness and/or work accidents and their managers. The study has as a parameter the reality of municipalities belonging to the Executive Management of INSS of São João da Boa Vista, SP. The data collection uses audio recording, identification card and script of interviews with authorization of the participants and, subject to content analysis, identifies two main categories: the work accident and / or illness and the return to work. It is concluded that the results of the research indicate that, feelings and behaviors aroused, can subsidize a new look from the manager to the rehabilitated, leading him to treat him in a more humane and respectful way, hoping that the return of the rehabilitated to the company does not always only fit to remain in the same function, to risk new accidents or to be disconnected from the company
\end{abstract}

Keywords: Professional Rehabilitation. Quality of life. Job. Professional Reintegration. Sustainable development.

Perspectivas em Gestão \& Conhecimento, João Pessoa, v. 8, n. 3, p. 40-66, set./dez. 2018. DOI: http://dx.doi.org/10.21714/2236-417X2018v8n3p40

http://periodicos.ufpb.br/ojs2/index.php/pgc. ISSN: 2236-417X. Publicação sob Licença (cc) EY-NC-ND 


\section{INTRODUÇÃO}

A construção deste estudo partiu da problematização de trabalhadores que se adoentaram ou se machucaram no ambiente de trabalho e que precisaram se afastar da empresa, recorrendo ao INSS, durante todo esse processo de transição, muitos foram marcados por transformações e humilhações, seguidas de dores físicas, emocionais, muitas vezes, para a vida toda (CESTARI; CARLOTTO, 2012).

Nota-se a necessidade de estudos mais aprofundados, o que justifica o presente estudo, o qual não pretende esgotar a discussão, mas contribuir para suscitar interesses voltados para essa temática.

Este trabalho teve como objetivo verificar qual é a percepção dos participantes em relação: a) história de vida após afastamento do trabalho; b) verificar como os participantes percebem essa reinserção ao ambiente laboral; c) relacionar a percepção dos participantes com a melhoria de vida e com os pilares da sustentabilidade.

\section{REFERENCIAL TEÓRICO}

A inaptidão laborativa produz dificuldades ao trabalhador de desempenhar suas funções de vida laboral, muitas vezes, esbarra nas dificuldades de ambiente físico e processos de recolocação em um determinado posto de trabalho, em decorrência de doenças ou acidentes, cujo dano não se traduz apenas às alterações funcionais, mas impactos psicológicos, mentais e físicos (MASSONI, 2012).

De acordo com a Organização Internacional do Trabalho (OIT, 2017), cerca de 2,3 milhões de pessoas morrem a cada ano como consequência de acidentes no trabalho, 160 milhões de pessoas sofrem de doenças não letais relacionadas com o trabalho e 317 milhões de acidentes laborais não mortais ocorrem a cada ano. Isto significada que: a cada 15 segundos, um trabalhador morre de acidentes ou doenças relacionadas com o trabalho e a cada 15 segundos, 115 trabalhadores sofrem um acidente laboral.

No Brasil são cerca de 700 mil acidentes de trabalho por ano, sendo a quarta nação do mundo que mais registra acidentes durante atividades laborais, atrás apenas da China, Índia e Indonésia. De acordo com os dados, entre 2012 e 2016, foram registrados 3,5 milhões de casos de acidente de trabalho em 26 estados e no Distrito Federal. Esses casos resultaram na morte de 13.363 pessoas e geraram um custo de $\mathrm{R} \$ 22,171$ bilhões para os cofres públicos com gastos da Previdência Social, como auxílio-doença, aposentadoria por invalidez, pensão por morte e auxílio-acidente para pessoas que ficaram com sequelas. Nos últimos cinco anos, 450 mil pessoas sofreram fraturas enquanto trabalhavam (OIT, 2017).

O avanço da tecnologia, a globalização e automação redefiniram a divisão de trabalho, impondo uma nova visão e novas formas de gerenciamentos onde se busca produtividade e qualidade do produto. Diante disso, cresce a terceirização e o contrato temporário em busca de uma maior flexibilização no uso do trabalho. A flexibilização acarreta diminuição de postos de trabalho, baixos salários, jornadas prolongadas, eclosão de novas doenças e mortes, desempregos e criação de subempregos (BARRETO, 2013).

Considerada como princípio básico da cidadania, na medida em que todos os cidadãos devem ter o direito e a dignidade de desenvolver suas potencialidades, a reabilitação profissional é um serviço da Previdência Social, que tem por objetivo proporcionar os meios de reeducação ou readaptação profissional para o retorno ao mercado de trabalho dos segurados incapacitados por doença ou acidente (INSS, 2014).

Embora a reabilitação profissional seja um direito preconizado pela Convenção no 159 da Organização Internacional do Trabalho - OIT, pela Lei 8.213/91 e clamada pela 3a Conferência 
Nacional de Saúde do Trabalhador, efetivamente, o aparato estatal oferece possibilidades limitadas para que esse processo ocorra (ROSSI et al., 2007).

Apesar de mais de 20 anos em que essa lei está em vigência, empresas ainda encontram dificuldades no cumprimento da mesma, por diversos motivos: falta de pessoas com deficiência interessadas nas vagas ofertadas, baixa escolaridade da pessoa com deficiência, ausência de políticas públicas adequadas (ROSSI et al., 2007).

A reabilitação profissional como é feita hoje apresenta limitações para todos os envolvidos, ou seja: reabilitados, INSS e empresa (SANTOS, 2009).

De um lado, trabalhadores desmotivados e inseguros em busca de consideração e valorização profissional. Reabilitados, muitas vezes, não querem voltar para empresa, resistentes a mudanças em relação à humilhação, desprezo e ódio da empresa. Do outro, empresas desgastadas, competitividade cada vez mais acirrada, desajuste em termos de clima organizacional; organizações que só buscam resultados e produtividade sem interesse pelo ser humano como um todo (CESTARI; CARLOTTO, 2012).

Trabalhadores brasileiros que por algum motivo passam a apresentar limitações físicas ou psíquicas para continuar a exercer a sua atividade de trabalho, são condenados a permanecerem em auxílio-doença por tempo prolongado ou mesmo de forma definitiva, ou são devolvidos para o mercado de trabalho desprovidos de qualquer possibilidade de se manterem (ROSSI et al., 2007).

Trabalhar com qualidade de vida passou a ser um dos resultados esperados tanto nas práticas assistenciais quanto nas políticas públicas, nos campos da promoção da saúde e da prevenção de doenças. Assim, saúde e doenças configuram processos relacionados a aspectos econômicos, socioculturais e experiências, promovendo uma atenção à saúde integral do trabalhador com maior possibilidade de um retorno ao trabalho sustentável, permanência e crescimento na atividade laborativa com a devida satisfação dos vários atores sociais (SEIDL; ZANNON, 2004).

É preciso promover uma reflexão em relação à importância de políticas públicas e uma melhor qualidade de vida para as pessoas que participam dos programas de reabilitação profissional, que esteja não só preocupada com a produtividade, mas que também desperte para a prática de valores nobres e uma convivência harmoniosa nas relações patrão/empregado e a reinserção destes funcionários afastados do mercado de trabalho, levando em conta seu potencial humano e produtivo (CESTARI; CARLOTTO, 2012).

\section{MÉTODOS}

Trata-se de estudo de casos múltiplos com abordagem qualitativa, por meio de entrevistas semiestruturadas, visto que busca conhecer, compreender e analisar alguns aspectos que permeiam a vivência de um grupo de pessoas específico (GIL, 2009).

Participaram do estudo dez trabalhadores reabilitados reintegrados após afastamento do trabalho, por um período superior a 30 dias, no intervalo de 10/07/2016 a 10/04/2017, de ambos os sexos, que trabalham ou trabalharam em empresas que possuem como parâmetro a realidade de municípios pertencentes a Gerência Executiva do INSS de São Joao da Boa Vista/SP.

Participaram também dez gestores e/ou chefes responsáveis pelos trabalhadores reabilitados, que já tenham liderado ou ainda liderem esses trabalhadores na empresa.

Segundo Yin (2010), estudo de casos múltiplos ocorrem quando vários estudos são conduzidos simultaneamente. Nesta pesquisa foram estudados vários indivíduos entre reabilitados e gestores

A coleta de dados ocorreu por meio de visitas realizadas em local escolhido pelo próprio entrevistado, conforme a disponibilidade de tempo e espaço de cada um. Após a leitura e posterior assinatura do Termo de Consentimento Livre e Esclarecido daqueles que concordaram em participar voluntariamente, deu-se sequência à aplicação do questionário de caracterização dos participantes (gênero, idade, grau de escolaridade, função na empresa e tempo de atuação na função) e as entrevistas foram baseadas em roteiro contendo 13 questões abertas sobre a reinserção destes 
trabalhadores, condutas e expectativas desses participantes em relação à volta ao trabalho após afastamento de maneira sustentável.

Os dados foram coletados e processados pelo software IRAMUTEQ (Interface de R pour les Analyses Multidimensionnelles de Textes et de Questionnaires), que tem por finalidade descobrir a informação essencial contida num texto, através de análise estatística textual. Embora se fale em análise quantitativa de dados textuais, essa não deixa de considerar a qualidade do fenômeno estudado, e ainda fornece critérios provenientes do próprio material, para a consideração do mesmo como indicador de um fenômeno de interesse científico (CAMARGO, 2005).

$\mathrm{O}$ autor afirma que o emprego de programas informáticos como o IRAMUTEQ proporciona o desenvolvimento de técnicas de análise de dados que beneficiaram as pesquisas sobre o fenômeno, o que justifica a sua utilização, além do caráter inovador que esse instrumento confere à análise dos discursos. Este software foi desenvolvido por Pierre Ratinaud, e para que se possa compreender a análise textual que realiza, é necessário inicialmente explicitar alguns conceitos importantes: 1) Corpus1 é o conjunto de textos que se pretende analisar. 2) Texto é cada entrevista que compõe o Corpus. Se uma determinada análise diz respeito às respostas de " $n$ " participantes a uma questão aberta, cada resposta será um texto, e teremos " $n$ " textos. 3) Segmentos de texto são partes do texto, na maioria das vezes, do tamanhos de três linhas, dimensionadas pelo próprio software. Assim, corpus, texto e segmentos de texto constituem o objeto de análise do IRAMUTEQ (CAMARGO; JUSTO, 2013).

O recurso Nuvens de Palavras utilizado como artifício suplementar à análise de conteúdos oferece distanciamento suficiente ao escrutínio isento conjugado ao envolvimento do pesquisador com proferimentos que, na perspectiva das metanarrativas, configurariam discursos e novos sentidos. Teriam a oferecer quadros conceituais úteis à síntese, sistematização e compreensão enriquecida de um conjunto de ideias que poderiam subsidiar proposições (MILLER, 2011).

A análise de similitude, também utilizado nesta pesquisa, baseia-se na teoria dos grafos (MARCHAND; RATINAUD, 2012) e possibilita identificar as co-ocorrências entre as palavras e seu resultado traz indicações da conexidade entre as palavras, auxiliando na identificação da estrutura da representação.

A realização deste estudo seguiu conforme o Conselho Nacional de Saúde: Resolução 466/12 que teve como objetivo o enfoque de pesquisa com seres humanos que, encaminhado, passou pela aprovação do Comitê de Ética em Pesquisa (CEP) do Centro Universitário das Faculdades Associadas de Ensino de São Joao da Boa Vista - FAE.

Com a aprovação do Comitê de Ética em Pesquisa (CEP), que garante aos participantes todos os direitos preconizados pela Resolução 196 do CNS (Conselho Nacional de Saúde) e a aprovação e exame de qualificação, iniciou-se a coleta de dados propriamente dita.

\section{RESULTADOS}

\subsection{Percepção dos Reabilitados}

A análise de conteúdo temático através da Nuvem de Palavras, possibilitou transcender aos proferimentos individuais por meio da organização, codificação, categorização e inferência dos conteúdos das entrevistas em seus respectivos contextos e nas suas conexões com as demais entrevistas (BARDIN, 2011). Buscou-se identificar núcleos de sentido, cujas similaridades compõem um conjunto de expressões a serem condensadas em categorias de análise que se referem a modelos mentais partilhados. Por meio de perspectivas, crenças e pontos de vista os indivíduos percebem, partilham e definem o seu lugar no mundo sob adversidades comuns. 
Figura 1: Análise de dados textual - Nuvem de palavras - reabilitados

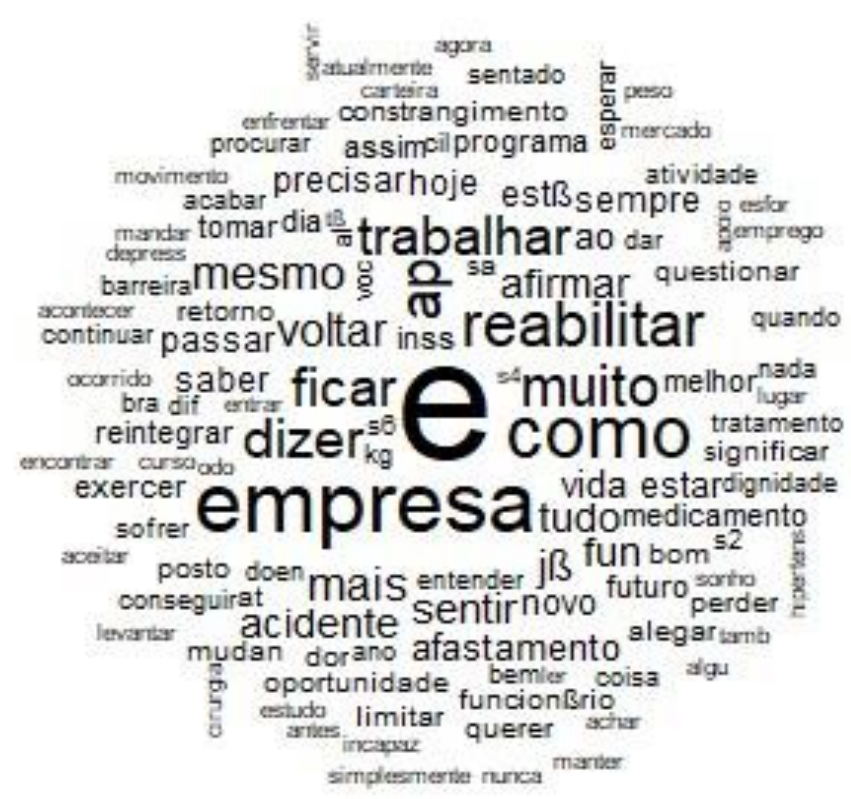

Fonte: Iramutec, 2018

No nível mais superficial de observação, é evidente o destaque às palavras EMPRESA e REABILITAR (Figura 1), No período de afastamento, os reabilitados alegam ter sentido tristeza, revolta, pois estavam acostumados a trabalhar. Além da falta de dinheiro. Sobre a palavra trabalho, os reabilitados fazem tudo com amor. Sentem esperança em sarar e conseguir voltar a trabalhar novamente, porém após o acidente tudo fica bem mais difícil em relação a encontrar uma nova chance no mercado de trabalho.

Conforme se observa na Figura 2, a árvore é apresentada na interface dos resultados da análise de similitude com a identificação das co-ocorrências entre as palavras e indicações da conexidade entre as termos: trabalhar, muita dor, empresa, afastamento, reabilitar, retorno, acidente, despesas, oportunidade auxiliando na identificação da estrutura do campo representacional dos fatores associados a reintegração dos reabilitados.

De acordo com a árvore de co-ocorrência, os resultados indicaram que os reabilitados necessitam trabalhar, se reintegrando à empresa para sentir sua dignidade de volta e ter esperança de dias melhores e que o afastamento só gera despesas e sofrimentos. 
Figura 2: Análise de similitude - Reabilitados

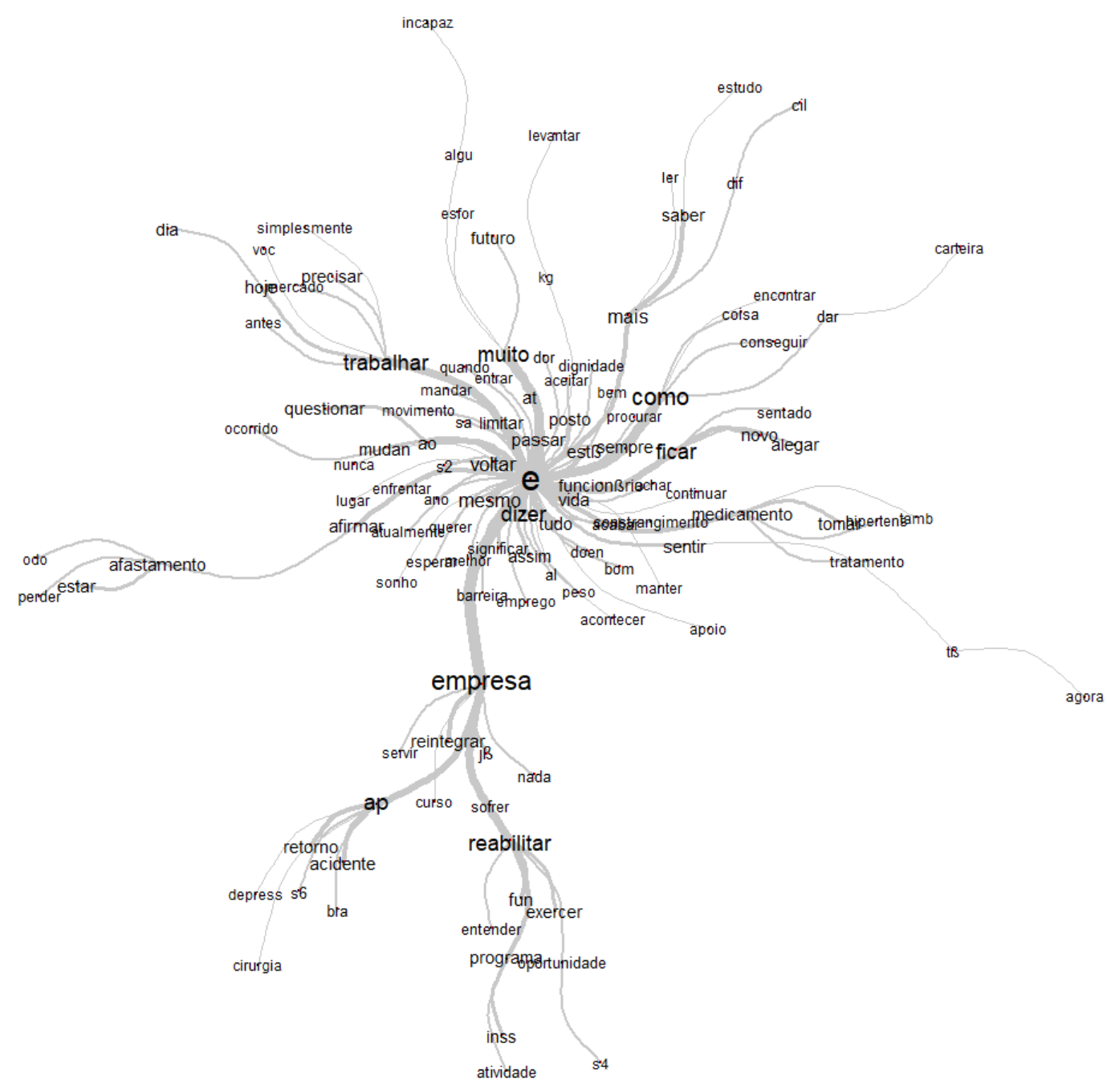

Fonte: Iramutec, 2018

Os quadros 1 e 2 sintetizam os resultados da análise. Participaram da pesquisa 10 pessoas, sendo $80 \%$ homens e $20 \%$ mulheres, com média de idade de 36,5 anos, com nível de instrução desde analfabetos a superior completo, pertencentes aos meios socioeconômicos de A à D.

Em sequência, são descritas as questões apresentadas aos reabilitados. Com o objetivo de preservar a identidade dos participantes da pesquisa, serão utilizados códigos de S1 à S10. 
Quadro 1: Dados pessoais dos reabilitados

\begin{tabular}{|c|c|c|c|c|c|c|c|c|c|c|}
\hline Sujeito & S1 & S2 & S3 & S4 & S5 & S6 & S7 & S8 & S9 & S10 \\
\hline Sexo & $M$ & $\mathrm{~F}$ & $M$ & $M$ & $M$ & $M$ & $M$ & $M$ & $\mathrm{~F}$ & $M$ \\
\hline Idade & 47 & 35 & 28 & 44 & 28 & 30 & 26 & 43 & 37 & 47 \\
\hline $\begin{array}{l}\text { Estado } \\
\text { Civil }\end{array}$ & Casado & Solteiro & Divorciado & Solteiro & Casado & Casado & Solteiro & Casado & Solteiro & Casado \\
\hline Filhos & 3 & 2 & 1 & 1 & 1 & 0 & 0 & 0 & 0 & 1 \\
\hline $\begin{array}{l}\text { Tipo de } \\
\text { moradia }\end{array}$ & Financiada & Própria & Alugada & Própria & Alugada & Própria & Financiada & Própria & Própria & Financiada \\
\hline $\begin{array}{l}\text { Mora com } \\
\text { quem }\end{array}$ & $\begin{array}{ll}\text { Esposa } & \text { e } \\
\text { filhos }\end{array}$ & Sozinha & Mãe & Pais & $\begin{array}{ll}\text { Esposa } & \mathrm{e} \\
\text { filho }\end{array}$ & Esposa & Mãe & Esposa & Sozinha & $\begin{array}{ll}\text { Esposa e } \\
\text { filho }\end{array}$ \\
\hline Religião & Católica & Católica & Evangélica & Evangélica & Católica & Espírita & Cristão & Espírita & Espírita & Católica \\
\hline $\begin{array}{l}\text { Escolarida } \\
\text { de }\end{array}$ & Analfabeto & $\begin{array}{l}\text { Médio } \\
\text { completo }\end{array}$ & $\begin{array}{l}\text { Fundamen } \\
\text { tal } \\
\text { completo }\end{array}$ & $\begin{array}{l}\text { Médio } \\
\text { completo }\end{array}$ & $\begin{array}{l}\text { Fundamen } \\
\text { tal } \\
\text { completo }\end{array}$ & $\begin{array}{l}\text { Médio } \\
\text { completo }\end{array}$ & $\begin{array}{l}\text { Superior } \\
\text { incomplet } \\
\text { o }\end{array}$ & $\begin{array}{l}\text { Médio } \\
\text { completo }\end{array}$ & $\begin{array}{l}\text { Superior } \\
\text { completo }\end{array}$ & $\begin{array}{l}\text { Fundamen } \\
\text { tal } \\
\text { completo }\end{array}$ \\
\hline $\begin{array}{l}\text { Curso de } \\
\text { qualificaçã } \\
\text { o na época } \\
\text { do } \\
\text { afastamen } \\
\text { to }\end{array}$ & $\begin{array}{l}\text { Não, nada } \\
\text { foi } \\
\text { oferecido }\end{array}$ & $\begin{array}{l}\text { Sim, } \\
\text { Técnico } \\
\text { em } \\
\text { Informática }\end{array}$ & $\begin{array}{l}\text { Não, nada } \\
\text { foi } \\
\text { oferecido }\end{array}$ & $\begin{array}{l}\text { Sim, Hab. } \\
\text { Gerais e } \\
\text { Técnico } \\
\text { em açúcar } \\
\text { e álcool }\end{array}$ & $\begin{array}{l}\text { Não, nada } \\
\text { foi } \\
\text { oferecido }\end{array}$ & $\begin{array}{l}\text { Sim, Hab. } \\
\text { Gerais e } \\
\text { Técnico } \\
\text { em RH }\end{array}$ & $\begin{array}{l}\text { Não, faz } \\
\text { por conta } \\
\text { um } \\
\text { tecnólogo. } \\
\text { O INSS } \\
\text { ajuda com } \\
\text { transporte }\end{array}$ & $\begin{array}{l}\text { Sim, Hab. } \\
\text { Gerais e } \\
\text { Técnico } \\
\text { em } \\
\text { Administra } \\
\text { ção }\end{array}$ & $\begin{array}{l}\text { Não, nada } \\
\text { foi } \\
\text { oferecido }\end{array}$ & $\begin{array}{l}\text { Sim, Hab. } \\
\text { Gerais }\end{array}$ \\
\hline
\end{tabular}

Fonte: Elaborado pelos autores, com base na pesquisa (2017) 
Quadro 2: Dados profissionais e de afastamento

\begin{tabular}{|c|c|c|c|c|c|}
\hline Sujeito & $\begin{array}{l}\text { Trabalho executado } \\
\text { antes do afastamento }\end{array}$ & $\begin{array}{l}\text { Trabalho executado } \\
\text { após reintegração }\end{array}$ & Tempo de afastamento & Motivo do afastamento & $\begin{array}{c}\text { Situação empregatícia } \\
\text { atual }\end{array}$ \\
\hline S1 & Serviços gerais & Não há posto compatível & 5 anos & $\begin{array}{l}\text { Doença }- \text { cirurgia } \\
\text { coluna, tornozelo } \\
\text { virilha }\end{array}$ & Afastado \\
\hline S2 & $\begin{array}{l}\text { Formação de muda de } \\
\text { laranja }\end{array}$ & Mesma função de antes & 4 anos & $\begin{array}{l}\text { Acidente de moto, fez } \\
\text { cirurgia no braço e ficou } \\
\text { imobilizada por } 5 \text { meses }\end{array}$ & Empregada \\
\hline S3 & $\begin{array}{l}\text { Trabalho braçal na } \\
\text { dobradeira }\end{array}$ & Mesma função de antes & 2 anos & $\begin{array}{l}\text { Acidente - } \begin{array}{ll}\text { travou } & \text { da } \\
\text { hérnia de disco na } \\
\text { empresa }\end{array} \\
\end{array}$ & Empregado \\
\hline S4 & $\begin{array}{l}\text { Mecânico } \quad \text { de } \\
\text { manutenção }\end{array}$ & $\begin{array}{l}\text { Não teve oportunidade } \\
\text { de } \\
\text { trabalha em outro local }\end{array}$ & 12 anos e 6 meses & $\begin{array}{l}\text { Acidente - caiu de uma } \\
\text { altura de } 5 \mathrm{mts} \text {, em pé. }\end{array}$ & Demitido (Justiça) \\
\hline S5 & $\begin{array}{l}\begin{array}{l}\text { Carregava sacos } \\
\text { cimento }\end{array} \\
\end{array}$ & Não há posto compatível & 3 anos & $\begin{array}{l}\text { Acidente - hérnias de } \\
\text { disco }\end{array}$ & Afastado \\
\hline S6 & $\begin{array}{l}\text { Operador de Produção } \\
\text { Qualificado }\end{array}$ & $\begin{array}{l}\text { Nova função - Operador } \\
\text { de Produção Comum }\end{array}$ & 6 anos & $\begin{array}{ll}\text { Doença } & - \\
\text { Osteossarcoma }\end{array}$ & Pediu demissão \\
\hline S7 & $\begin{array}{ll}\text { Repositor } & \text { de } \\
\text { mercadorias } & \end{array}$ & Não há posto compatível & 6 anos & Acidente - Moto & Afastado \\
\hline S8 & Operador Industrial & Não foi reintegrado & 4 anos & $\begin{array}{l}\text { Acidente }- \text { esforço } \\
\text { demasiado causou } 3 \\
\text { hérnias de disco }\end{array}$ & Demitido \\
\hline S9 & Arrecadador & Arrecadador & 90 dias & $\begin{array}{l}\text { Doença - tenossinovite - } \\
\text { inflamação da bolsa } \\
\text { sinovial que contorna o } \\
\text { tendão, esp. dos dedos e } \\
\text { artelhos }\end{array}$ & Pediu demissão \\
\hline S10 & $\begin{array}{l}\text { Ajudante Geral e } \\
\text { Empilhadeira }\end{array}$ & Mesma função & 4 anos & $\begin{array}{l}\text { Doença - problema no } \\
\text { braço }\end{array}$ & Demitido \\
\hline
\end{tabular}

Fonte: Elaborado pela autora, com base na pesquisa (2017)

Perspectivas em Gestão \& Conhecimento, João Pessoa, v. 8, n. 3, p. 40-66, set./dez. 2018. 
Ao ser questionado sobre o que entende reabilitação profissional, o S1 alega não saber como funciona, nem como é, já que não houve reintegração na empresa. Afirma que ao se afastar, há mais ou menos 5 anos atrás, a empresa o procurou e emprestou $\mathrm{R} \$ 750,00$ para fazer uma ressonância magnética, e, após isso não apareceram mais.

No período de afastamento, o mesmo alega ter sentido tristeza, ficou revoltado, pois estava acostumado a trabalhar. $\mathrm{E}$, além disso, sem dinheiro tudo é mais difícil, restando apenas a se apegar a Deus. Sobre o significado da palavra trabalho, o S1 disse que apesar de não ter estudo, sempre faz tudo com amor e sem o trabalho não se vive. Mostra esperança em sarar e conseguir voltar a trabalhar novamente, porém como não sabe ler nem escrever relata que tudo fica bem mais difícil em relação a encontrar uma nova chance no mercado de trabalho.

De acordo com Ramos et al (2008), o trabalho como uma temática relacionada à inclusão e/ou exclusão social está associada às condições fornecidas pelo ambiente e como essas potencializam e possibilitam espaços de produção e invenção nos ambientes de trabalho. Com tudo, a saúde está relacionada também com a tolerância as infidelidades do meio. Essas intolerâncias podem vir a gerar diminuição na produtividade do indivíduo bem como acidentes e afastamentos do trabalho.

Afirma que a cirurgia feita na coluna, no tornozelo e na virilha foi um sucesso, mas ainda está em tratamento e usa medicamento diariamente para hipertensão. Não passou por constrangimento nenhum, pelo contrário, as pessoas com quem conversa, o admiram pelos problemas que passou e, mesmo assim, ainda querer voltar a trabalhar. Conta com o apoio da esposa que o ajuda e dá muita força também. Após o afastamento, afirma que a pior parte foi perder o carro que comprou com tanto sacrifício, já que não recebia para pagar o financiamento.

Ao ser questionado sobre o futuro, responde:

"Quero fazer o que sei fazer, eu sou assim, faço tudo com muito amor e carinho. Mas eu não tenho escolha, porque não tenho estudo nenhum, então o que me mandar fazer, eu aceito. Aí eu vou em frente, aceito o que for e vou" (S1, set/2016).

O S2 entende por reabilitação profissional que teria que ser enquadrado em uma área onde caberia suas limitações após o acidente, conforme previsto na legislação.

A reabilitação profissional é um serviço da Previdência Social, prestado pelo Instituto Nacional da Seguridade Social - INSS, que tem por objetivo proporcionar os meios de reeducação ou readaptação profissional para o retorno ao mercado de trabalho dos segurados e seguradas incapacitados por doença ou acidente, em caráter obrigatório, meios indicados para a reinserção no mercado de trabalho, segundo a lei no 8.213, de 24 de julho de 1991 (BRASIL, 2014).

Após o afastamento, a empresa questionou se estava preparada para o retorno ao trabalho. Alega que o afastamento foi muito deprimente, chorava muito, perdeu os sonhos, já que após a cirurgia, ficou limitada de levantar o braço para trás e após isso, teve necrose no braço. Estava aguardando a nova cirurgia pelo SUS, quando foi liberada pelo INSS para voltar a trabalhar.

A respeito de trabalho, $\mathrm{S} 2$ diz que significa autoestima, sempre foi independente, sempre dirigiu e foi assim que construiu o que ela tem hoje. Após passar pelo Programa de Reabilitação Profissional do INSS, S2 diz que voltou a mesma função de antes do acidente, porém trabalha de acordo com seus limites, não pode elevar o braço mais que 50 o e é necessário evitar o levantamento de peso.

Sofreu alguns constrangimentos, como: 


\begin{abstract}
“Agora você tá boa prá trabalhar, já deu de descanso. Já tá na hora de voltar mesmo. Você é apenas aleijadinha, não é deficiente. Não me vejo como profissional. Não me vejo encaixada em nenhum lugar. O governo tá difícil. Agora não tenho mais saúde. Sobre o futuro, não sei, não tenho esperança, eu perdi, me sinto assim. É muito difícil pensar no futuro, sendo que no presente eu estou sofrendo demais" (S2, set/2016).
\end{abstract}

A saúde está comprometida, toma medicamento para infecção de urina e rim, devido a estufa ser um lugar muito quente. A empresa oferece água e soro neste caso. Sofre de hipertensão também.

Diz que não saberia o que seria se não fosse a família. Os pais moram na roça, mas a traziam todos os dias na fisioterapia. Teve apoio dos amigos no começo, quando aconteceu o acidente, hoje não mais.

Ao ser questionada sobre as mudanças ocorridas em sua vida após o acidente, S2 alega que mudou seu emocional, que saía muito, e depois do acidente precisou ficar 1 ano e $1 / 2$ se cuidando para voltar o movimento do braço, muito repouso. Além disso, precisou vender o carro, pois não tinha como manter e está cheia de dívidas até hoje.

Sobre reabilitação profissional, S3 entende ser para se adaptar em outra função que consiga trabalhar. A empresa não fez nada pós seu afastamento, só questionou se estava preparado para voltar, dizendo "vai lá que o serviço é seu". Afirma que no período de afastamento perdeu tudo, a família, casa, filha. Entrou em depressão, chegou a pesar $122 \mathrm{~kg}$, e tinha muita briga. Acabou por sair de casa com a TV e o videogame.

Alega que o trabalho significa tudo, é a sobrevivência para manter a vida, é a dignidade. $E$ como não pode fazer mais nada, se sair da empresa não sabe o que acontecerá. Não foi chamado pelo INSS para o Programa de Reabilitação Profissional. Ao voltar do afastamento, não houve nenhum tipo de reintegração, simplesmente chegou e foi fazer seu trabalho.

A reintegração dos trabalhadores que se encontram parcialmente incapacitados, por motivo de doença ou acidente, é um processo complexo que depende do padrão de interação entre as várias instâncias: trabalhador, INSS, empresa de vínculo e família (CESTARI; CARLOTTO, 2012).

A principal barreira enfrentada é a incapacidade. De $130 \mathrm{~kg}$ que levantava, hoje só pode trabalhar com $5 \mathrm{~kg}$. Se sente totalmente incapaz. Mas está desempenhando bem a função, desde que não se agache e não levante peso.

Afirma ter passado por muito constrangimento, pois, pelo seu tamanho só consegue levantar $5 \mathrm{~kg}$. Não toma nenhuma medicação. Perdeu tudo e voltou a morar com a mãe que é quem o apoia em tudo. Agora começou a reconstruir sua vida "tenho até uma namorada".

Sobre as mudanças ocorridas após o acidente, diz que tudo que faz tem que ser devagar, sem muito esforço e, principalmente, sem movimentos bruscos.

\footnotetext{
“Me vejo como alguém incapaz, não posso fazer mais nada. Meu futuro está nas mãos de Deus, porque como não tenho estudo, não sei o que vou arrumar. É muito triste. Mas de uma coisa tenho certeza: trabalhar sempre!" (S3, out/2016).
}

Sobre a reabilitação profissional, o S4 afirma que é um incentivo para acreditar que se é capaz de exercer outra função, na qual você ficou incapacitado de trabalhar, trazendo nova oportunidade no mercado de trabalho. Teve depressão, se sentia inútil, descriminado. Sem dignidade, já que este é o significado da palavra trabalho a seu ver.

O Programa de Reabilitação Profissional e sua ação de auxiliar o retorno ao trabalho estão assegurados através da Constituição Federal. O Ministério da Previdência e Assistência Social 
administra essa ação por meio do INSS. Trata-se de um serviço que tem como objetivo proporcionar aos segurados e dependentes incapacitados (parcial ou totalmente) os meios indicados para a (re) educação e (re) adaptação profissional e social, de modo que possam voltar a participar do mercado de trabalho, (MPAS, 2001).

S4 diz que não teve oportunidade, após a reabilitação profissional, de reintegração na empresa em que sofreu acidente, a empresa simplesmente se negou, não o incentivando a fazer nenhum curso que poderia reabilitá-lo. Sendo assim precisou se submeter a trabalhar como entregador de leite, serviço pesado, que exigia muito esforço da coluna. Mas não podia ter outro serviço com carteira registrada, pois a empresa não deu baixa em sua carteira profissional. Hoje em dia trabalha como monitor em uma creche de idosos.

\begin{abstract}
"Após passar pelo Programa de Reabilitação Profissional do INSS, não voltei a exercer a atividade de antes, pois as portas se fecharam, já que não posso ser registrado por conta que a empresa na qual eu trabalhava não me reabilitou, não me mandou embora e não deu baixa na minha carteira, sendo eu obrigado a entrar com ação judicial trabalhista. Essa ação já julgada e com sentença a meu favor" (S4, out/2016).
\end{abstract}

Encontrou várias barreiras desde fazer um curso que não tem nada a ver com o que a empresa produz, diminuir salario até ter negada a vaga de deficiente, com a desculpa que já estavam com o quadro de funcionários completo e que já haviam contratado além dos $3 \%$ que é cobrado por lei.

S4 toma medicamento para hipertensão, e afirma que uma mudança boa ocorrida foi parar com o álcool e o fumo. Mas também passou por dificuldade financeira, as constantes dores, as perdas de oportunidades de empregos melhores.

\footnotetext{
"Eu me vejo como um profissional perseverante, capaz, responsável e dedicado, e, para meu futuro, espero o melhor. Um emprego melhor, com melhor remuneração, ser reconhecido e valorizado" (S4, out/2016).
}

Sobre a reabilitação profissional, S5 diz que acha que é um curso que é ministrado para aprender novas funções após o acidente. Afirma sentir muita dor física, além da dor emocional, desespero, muita raiva. Ao ser questionado sobre o que significa o trabalho, responde somente "dignidade".

Em geral, muitas organizações não consideram outras habilidades e aptidões para a pessoa exercer uma nova função, que agora é outra, compatível com a sua realidade e situação. Neste sentido, é imprescindível que se estabeleça uma parceria produtiva entre trabalhador, INSS e empresas vinculadas (CESTARI; CARLOTTO, 2012).

Continua afastado. Não houve reintegração na empresa, nunca recebeu nem um telefonema.

\footnotetext{
"Acho que nunca mais vou arrumar um emprego decente. Não posso ficar muito tempo nem sentado e nem deitado que trava tudo" (S5, nov/2016).
}

Já passou por alguns constrangimentos. As pessoas dizem querer ter a vida que $\mathrm{S} 5 \mathrm{tem}$, mas ele diz que queriam que tivessem na pele dele. Sente muita dor, toma medicamento, ou tem que ir para o hospital tomar soro. Não pode nem pegar a filha nos braços. Não pode levantar mais que 20 $\mathrm{kg}$. 
"É uma limitação. Não me sinto a pessoa que nasci. Não foi minha culpa, faltou apoio da empresa" (S5, nov/2016).

Sobre reabilitação profissional S6 diz que deveria ser requalificado a ponto de continuar sendo útil e eficaz para a empresa, de modo que possa exercer determinada função igual a qualquer outro funcionário.

Após seu retorno, a empresa não fez o combinado. Ao visitar a empresa a procura de um novo posto devido as suas limitações na perna, por não poder ficar em pé por muito tempo, a empresa, diante de um médico do INSS, determinou um trabalho onde ficava sentado e a produção era somente manual. Porém quando voltou ao trabalho, não foi assim que aconteceu.

Uma avaliação criteriosa sobre a atividade a ser realizada pelo trabalhador, análise que deve avaliar não somente suas condições físicas, técnicas e operacionais, mas também suas condições emocionais. As ações devem contemplar uma retomada na trajetória profissional do trabalhador segurado, considerando que sua incapacidade laboral não envolve somente um recomeço a partir de uma sequela física, um retorno à possibilidade de sustento, significa, ademais, a retomada de sua autoestima, identidade, autonomia e inclusão social, (CESTARI; CARLOTO, 2012).

No período de afastamento, S6 diz que sentiu medo de não poder voltar a fazer o que sempre fez, medo de precisar depender sempre de outras pessoas. Afirma que trabalho é como uma arte para ele, onde através da habilidade que tem consegue fazer com que outras pessoas fiquem felizes por estarem usufruindo daquilo que se fez com tanto carinho.

Após ter passado pelo Programa de Reabilitação Profissional do INSS, S6 não está exercendo a atividade para a qual foi reabilitado. Também não houve qualquer tipo de reintegração ou orientação específica da empresa após seu retorno.

\begin{abstract}
"Eu sempre fui um funcionário exemplar, portanto na segunda semana de trabalho naquele posto onde era prá eu ficar fixo, fui retirado para ajudar na produção de linha comum (em pé) mesmo contra a minha vontade e aptidão física. Aceitei, pois me disseram que eu não era nenhum queridinho e que era uma funcionário normal, concordei imediatamente com a afirmação e fui para o posto que mandaram, fiquei lá por cerca de 1 ano (em pé), onde o mesmo alegou que eu não poderia ficar sentado, pois ele me pagava para produzir" (S6, nov/2016).
\end{abstract}

S6 viu o descaso como a maior barreira encontrada após seu retorno. Nem mesmo seus superiores o tratavam como um funcionário comum, fazendo-o se sentir inferior. Ele necessitava de um posto que tivesse uma cadeira por causa da limitação e sua perna (ficou com $5 \mathrm{~cm}$ de diferença entre uma e outra). Seu desempenho era o mesmo de outros operadores daquele setor, porém só ficou duas semanas neste setor.

Sentiu muito constrangimento, dizendo que todo dia era motivo de uma nova piada por precisar trabalhar sentado. Hoje em dia, a saúde está bem, faz acompanhamento preventivo anualmente e não precisa mais de medicamentos.

A respeito de seus relacionamentos com familiares e amigos, é muito bom, apesar que sempre acham que ele precisa de "ajuda". A doença mudou em $100 \%$ sua vida, por causa das limitações, não consegue fazer coisas simples, como correr, caminhar por longos períodos, etc.

\footnotetext{
“Mas me vejo como um ótimo profissional, por isso, saí da empresa onde trabalhava e montei meu próprio negócio, e tenho total certeza que, se um dia, um funcionário meu for reabilitado, ele terá toda atenção que merece! (S6, nov/2016)"
} 
Reabilitação profissional é engajar o indivíduo no mercado de trabalho de acordo com suas limitações após o acidente ou doença. S7 não voltou a empresa que trabalhava antes do acidente de moto, que atrasou seus sonhos, as coisas que queira fazer.

Jacques e Codo (2002) afirmam que algumas pessoas ao longo de suas vidas, naturalmente conseguem conquistar competências para vivenciar suas próprias histórias profissionais. Outras, por meio das características e circunstâncias de seus trabalhos, não conseguem dar continuidade aos seus projetos de vida, onde para essas pessoas que sofrem algum tipo de acidente ou adoecimento no trabalho existe o Serviço da Previdência Social.

Para S7, trabalho significa algo que se faz em troca de remuneração, e, que se gostar de fazer, acaba virando lazer. Afirma não ter sentido constrangimento e não estar passando por tratamento nem tomando medicamentos atualmente e que o afastamento atrasou seus sonhos e todas as coisas que gostaria de fazer na vida como frequentar academia, praticar esporte e crescer profissionalmente

"Estou buscando aperfeiçoar meus conhecimentos para ter uma vida melhor. Eu preciso melhorar de vida" (S7, nov/2016).

S8 foi bem enfático ao dizer que o programa de reabilitação profissional não funciona bem e que a empresa, na maioria das vezes, espera vencer 1 ano de estabilidade e depois dispensa o funcionário que passou por acidente de trabalho. Afirma sentir muita frustação e desesperança.

Diz que trabalho significa dignidade, e que atualmente não está exercendo a atividade para qual foi reabilitado pelo Programa de Reabilitação Profissional do INSS.

A ligação entre o mercado de trabalho e o trabalhador terá como significado a igualdade de direitos, a capacidade de gerar resultados e, acima de tudo, mostrar que suas restrições não representam obstáculos para a execução de determinadas tarefas (OLIVEIRA; SILVA; PALAZI, 2007).

A empresa simplesmente não sabia o que fazer com ele. Ficou 3 dias esperando por uma posição. Sentiu descaso total da empresa. Hoje em dia não está mais na empresa, foi demitido. Continua o tratamento até hoje. As mudanças ocorridas foram todas inimagináveis

\footnotetext{
"A gente nasceu pobre, não tem muita opção, tem que continuar a luta de um jeito ou de outro. É muito duro não ser respeitado, humilhado e até mesmo visto como alguém que não deu certo" (S8,dez/2016).
}

De acordo com S9:

\begin{abstract}
"Reabilitação profissional é um programa criado pela empresa com profissionais qualificados, para preparar tanto psicologicamente, quanto fisicamente o reabilitado para a nova função" (S9, dez/2016).
\end{abstract}

As empresas, por seu lado, percebem as dificuldades que os sujeitos têm para o retorno ao trabalho, pois é a organização quem determina o grau de participação dos trabalhadores na realização das atividades. O que ocorre, muitas vezes é que não há uma preocupação em definir um novo posto de trabalho ou fazer alguns reajustes no trabalho a estes reabilitados, que haviam sido antes realizados anteriormente (CESTARI; CARLOTTO, 2012).

A empresa manteve $S 9$ no mesmo posto de trabalho, porém em uma nova função, desta maneira houve reintegração ou orientação específica após seu retorno. Houve rejeição dos colegas 
de trabalho e sentiu muito preconceito, apesar disso, nunca se sentiu constrangida. Não toma medicamentos e nem faz tratamento atualmente.

As principais mudanças foram as restrições para algumas atividades, mas essas mudanças colaboraram para um futuro profissional melhor. S9 se vê como uma ótima profissional em tudo que se propõe a fazer e no futuro espera ter muito crescimento profissional.

O S10 entende reabilitação profissional como uma oportunidade para ser uma pessoa melhor em uma outra função compatível com cada caso.

Diz que o tipo de trabalho que exercia acabou por agravar a doença que já existia, visto que na empresa exercia multi-funções, e era conhecido como "o faz tudo". Se afastou por 3 vezes e quando retornava, o RH da empresa o colocava no mesmo lugar, mesmo sendo aconselhado pelo médico a não fazer esforço. Não houve nenhum tipo de reintegração por parte da empresa após o retorno do afastamento.

De acordo com Cestari e Carlotto (2012) a experiência do afastamento do trabalho vem a ser marcado pela incapacidade e insegurança, mas outros fatores como a flexibilização do trabalho, o risco de desemprego e as dificuldades encontradas dentro do ambiente organizacional e a busca pelos seus direitos acarretam também complicações psicológicas.

Houve preconceito por parte dos colegas de trabalho, como se ele não prestasse mais para a empresa, como se não tivesse valor nenhum. A empresa deveria enxergar o trabalhador como um ser que precisa ter qualidade de vida, e isso não acontece.

Como barreiras enfrentadas, foi o trabalho com dor. Tinha que voltar a trabalhar, mas sentia muita dor. E não existia um posto de trabalho compatível com a sua doença. S10 era uma pessoa muito dinâmica, alegre, extrovertida e após o problema enfrentado, foi se fechando e quase acabou entrando em depressão.

"Como eu ficava pulando de função em função, ficava excedente e mesmo assim, eu trabalhava mais que os outros. A empresa me dispensou após fechamento da mesma. Hoje trabalho como autônomo. Mas não posso carregar peso e nem com movimentos repetitivos. Meu conselho para quem passar pelo mesmo é: procure seus direitos. Você tem direitos. Procure um bom advogado. Para a empresa o que posso dizer é dê oportunidades para o reabilitado, ele não é um aleijado, um incapaz. Falta alguém que apresente essas oportunidades na empresa" (S10, 2017)

\subsection{Percepção dos gestores}

Na figura 3, ficou evidente, também, o destaque às palavras EMPRESA e REABILITA. Porém, conforme será visto nas entrevistas, em outro sentido. O processo de reinserção do reabilitado deveria ser como uma oportunidade para que volte a ter seu trabalho e sua dignidade. Dentre as dificuldades em lidar com o reabilitado, seria descobrir a real limitação do mesmo, entender o que ele precisa e como reagirá junto aos colegas de trabalho. 
Figura 3: Análise de dados textual - Nuvem de Palavras - Gestores

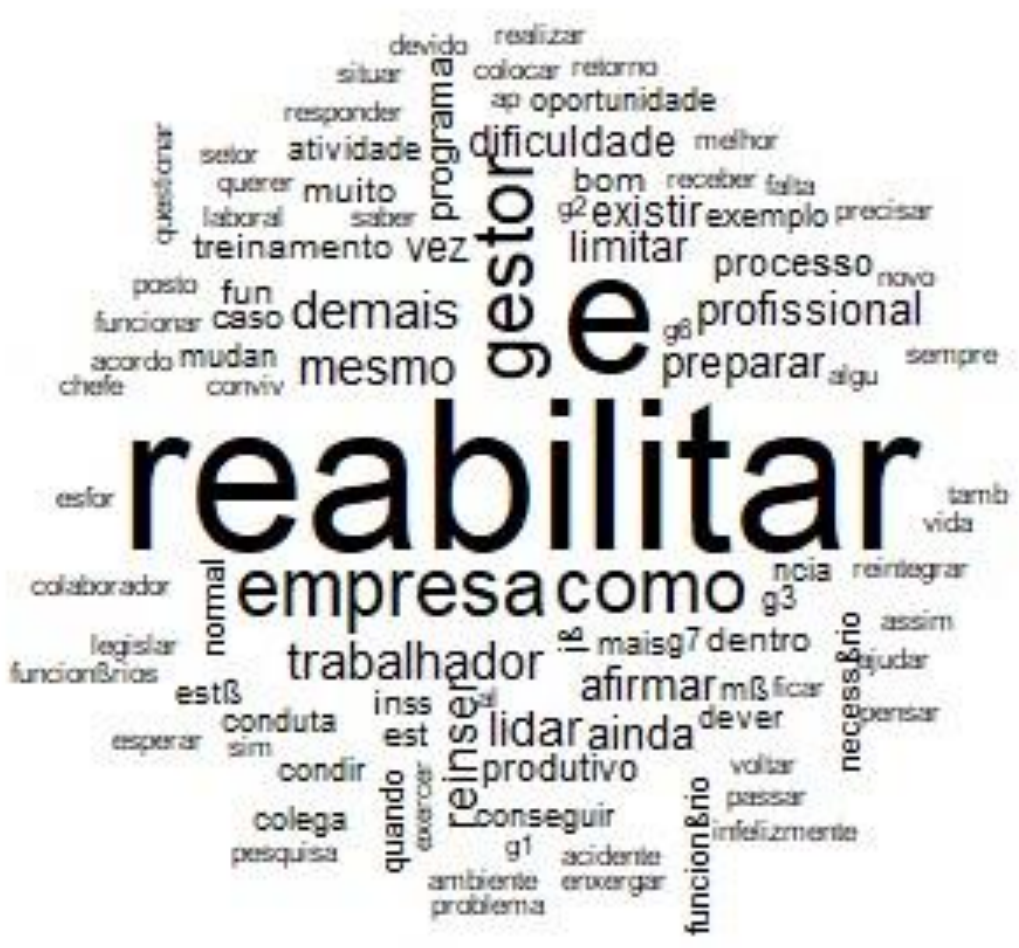

Fonte: Iramutec (2018)

Conforme se observa na Figura 4, a árvore é apresentada na interface dos resultados da análise de similitude com a identificação das co-ocorrências entre as palavras e indicações da conexidade entre as termos: reabilitar, gestor, empresa, treinamento, oportunidades. 
Figura 4: Análise de Similitude - Gestores

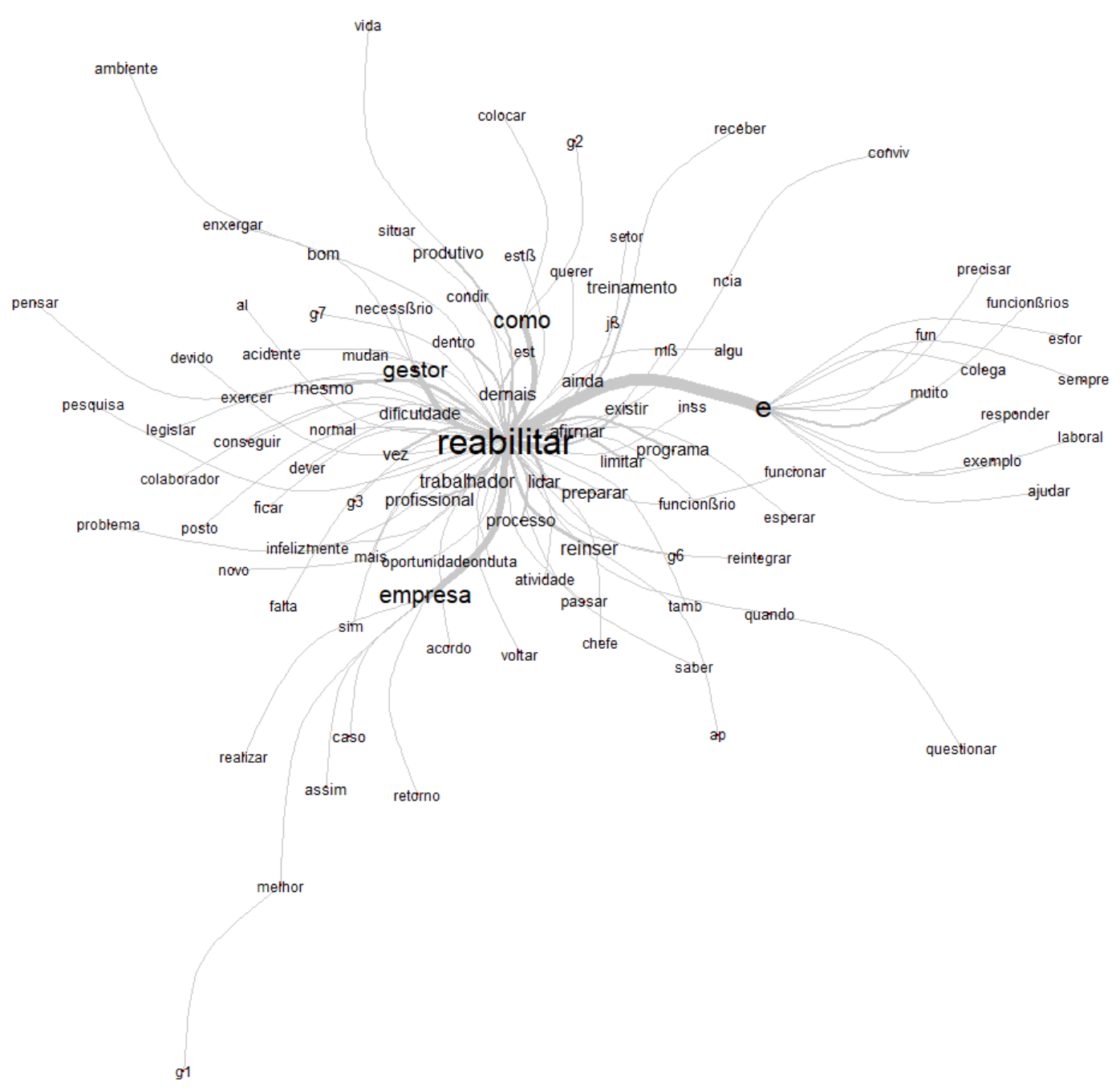

Fonte: Iramutec (2018)

Os resultados indicam que a reabilitação profissional é um recomeço, uma nova oportunidade de trabalho. A preparação dos gestores para lidar com os reabilitados, necessita de melhores treinamentos, tanto para o gestor quanto para a empresa.

O processo de reinserção do reabilitado deveria ser como uma oportunidade para que volte a ter seu trabalho e sua dignidade.

Os quadros 3 e 4 sintetizam os resultados da análise. Participaram da pesquisa 10 gestores, sendo 9 homens e 1 mulher, com idade entre 39 e 55 anos, com nível de instrução superior completo, pertencentes aos meios socioeconômicos A e B.

A seguir, são descritas as questões apresentadas aos gestores. Com o objetivo de preservar a identidade dos participantes da pesquisa, serão utilizados códigos de G1 à G10. 
Quadro 3: Dados pessoais dos gestores

\begin{tabular}{|c|c|c|c|c|c|c|c|c|c|c|}
\hline Gestor & G1 & $\mathrm{G} 2$ & G3 & G4 & G5 & G6 & G7 & G8 & G9 & G10 \\
\hline Sexo & $M$ & $M$ & $M$ & $M$ & $M$ & $M$ & $M$ & $M$ & $M$ & $\mathrm{~F}$ \\
\hline Idade & 45 & 51 & 55 & 39 & 49 & 45 & 40 & \multirow{7}{*}{ 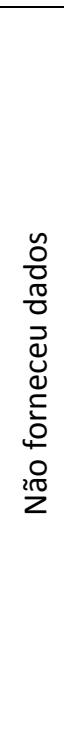 } & \multirow{7}{*}{ 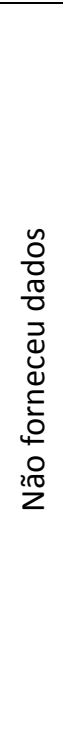 } & \multirow{7}{*}{ 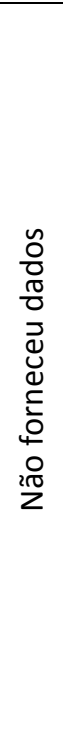 } \\
\hline Estado Civil & Divorciado & Casado & Casado & Casado & Casado & Casado & Casado & & & \\
\hline Filhos & 2 & 1 & 2 & 1 & 2 & 3 & 0 & & & \\
\hline $\begin{array}{l}\text { Mora com } \\
\text { quem }\end{array}$ & Filhos & $\begin{array}{l}\text { Esposa e } \\
\text { filhos }\end{array}$ & $\begin{array}{l}\text { Esposa e } \\
\text { filhos }\end{array}$ & $\begin{array}{l}\text { Esposa e } \\
\text { filhos }\end{array}$ & Esposa & $\begin{array}{l}\text { Esposa e } \\
\text { filhos }\end{array}$ & Esposa & & & \\
\hline Religião & Católica & Católica & $\begin{array}{l}\text { Testemunha } \\
\text { de Jeová }\end{array}$ & Católica & Católica & Católica & Cristão & & & \\
\hline Escolaridade & $\begin{array}{l}\text { Superior } \\
\text { completo }\end{array}$ & $\begin{array}{l}\text { Superior } \\
\text { completo }\end{array}$ & $\begin{array}{l}\text { Superior } \\
\text { completo }\end{array}$ & $\begin{array}{l}\text { Superior } \\
\text { completo }\end{array}$ & $\begin{array}{l}\text { Superior } \\
\text { completo }\end{array}$ & $\begin{array}{l}\text { Superior } \\
\text { completo }\end{array}$ & $\begin{array}{l}\text { Superior } \\
\text { completo }\end{array}$ & & & \\
\hline $\begin{array}{l}\text { Curso } \\
\text { relacionado } \\
\text { à área de } \\
\text { atuação }\end{array}$ & Não & $\begin{array}{l}\text { Sim, } \\
\text { Gestão de } \\
\text { Qualidade }\end{array}$ & $\begin{array}{l}\text { Sim, } \\
\text { Medicina e } \\
\text { Segurança } \\
\text { do Trabalho }\end{array}$ & $\begin{array}{l}\text { Sim, } \\
\text { Gestão de } \\
\text { Qualidade }\end{array}$ & $\begin{array}{l}\text { Sim, Engenharia } \\
\text { Ambiental, } \\
\text { Engenharia e } \\
\text { Segurança do } \\
\text { Trabalho e } \\
\text { Higiene } \\
\text { Organizacional }\end{array}$ & $\begin{array}{l}\text { Sim, } \\
\text { Gestão de } \\
\text { Produção }\end{array}$ & $\begin{array}{l}\text { Sim, } \\
\text { Automação } \\
\text { Industrial }\end{array}$ & & & \\
\hline
\end{tabular}

Fonte: Elaborado pela autora, com base na pesquisa (2017) 
Quadro 4: Dados profissionais dos gestores

\begin{tabular}{|c|c|c|c|c|c|}
\hline Gestor & Função que exerce & $\begin{array}{c}\text { Quanto tempo na } \\
\text { empresa }\end{array}$ & $\begin{array}{l}\text { Já exerceu outra função } \\
\text { que não a de gestor }\end{array}$ & Porte da Empresa & Setor de Atuação \\
\hline G1 & Líder de Produção & 10 anos & Não & Médio & Indústria \\
\hline G2 & $\begin{array}{ll}\text { Coordenador } & \text { de } \\
\text { Produção } & \\
\end{array}$ & 10 anos & $\begin{array}{l}\text { Sim, Analista de } \\
\text { Processos }\end{array}$ & Médio & Indústria \\
\hline G3 & $\begin{array}{l}\text { Segurança e medicina do } \\
\text { trabalho }\end{array}$ & 11 anos & Não & Grande & Indústria \\
\hline G4 & $\begin{array}{l}\text { Coordenador de } \\
\text { Produção }\end{array}$ & 15 anos & Sim, Analista de PCP & Médio & Indústria \\
\hline G5 & $\begin{array}{l}\text { Analista de Segurança do } \\
\text { Trabalho }\end{array}$ & 6 anos & Não & Grande & Indústria \\
\hline G6 & Líder de Produção & 10 anos & $\begin{array}{l}\text { Sim, Coordenador de } \\
\text { PCP }\end{array}$ & Grande & Indústria \\
\hline G7 & Líder de Produção & 13 anos & Não & Grande & Indústria \\
\hline G8 & Não forneceu & Não forneceu & Não forneceu & Médio & Indústria \\
\hline G9 & Não forneceu & Não forneceu & Não forneceu & Médio & Indústria \\
\hline G10 & Diretora & Não forneceu & Não forneceu & Médio & Indústria \\
\hline
\end{tabular}

Fonte: Elaborado pela autora, com base na pesquisa (2017) 
O trabalhador reabilitado enxerga o gestor como uma pessoa que acredita em sua capacidade de recomeçar. Existiram casos em que o reabilitado apresentou má conduta na empresa, muitos gostam do setor, do grupo e quando se fala em mudança se revoltam e não querem.

Para a G1, reabilitação profissional é um recomeço, uma nova oportunidade de trabalho. Neste sentindo, a reabilitação profissional é um serviço da Previdência Social, prestado pelo Instituto Nacional da Seguridade Social - INSS, que tem por objetivo proporcionar os meios de reeducação ou readaptação profissional para o retorno ao mercado de trabalho dos segurados e seguradas incapacitados por doença ou acidente, em caráter obrigatório, meios indicados para a reinserção no mercado de trabalho, segundo a lei no 8.213, de 24 de julho de 1991 (BRASIL, 2014).

Quando questionado sobre a preparação dos gestores para lidar com os reabilitados, G1 diz que ainda falta melhores treinamentos, tanto para o gestor quanto para a empresa. E que o Programa de Reabilitação Profissional, infelizmente, muitas vezes não prepara o reabilitado para seu retorno à empresa.

O processo de reinserção do reabilitado deveria ser como uma oportunidade para que volte a ter seu trabalho e sua dignidade. Dentre as dificuldades em lidar com o reabilitado, a G1 citou descobrir a real limitação do mesmo, entender o que ele precisa e como reagirá junto aos colegas de trabalho.

Afirmou ainda, que alguns reabilitados continuam tão produtivos quanto os demais trabalhadores. Já outros não respondem de acordo com o que se pede, mesmo existindo amizade e camaradagem entre eles.

\footnotetext{
"Após a reinserção de trabalhadores reabilitados, aconteceram algumas mudanças, tanto boas quanto ruins. Alguns reabilitados usaram suas limitações para não ter que trabalhar. Enquanto existem outros que são exemplos de esforço e responsabilidade, até para outros colegas de trabalho" (G1, jan/2017).
}

G1 se enxerga como um gestor que gosta muito do seu trabalho e que busca sempre ser cada vez melhor.

Para G2, ele é visto pelo reabilitado como um chefe normal, e nunca teve um caso de má conduta por parte de um reabilitado na empresa.

\footnotetext{
“Reabilitação profissional quer dizer criar condições para o reabilitado voltar a ser uma pessoa com suas habilidades de desempenho plenamente desenvolvidas" (G2, jan/2017).
}

Afirma que os gestores estão preparados para lidar com o trabalhador reabilitado e que o Programa de Reabilitação Profissional foi muito favorável no caso que teve, para preparar o reabilitado para seu retorno à empresa. O processo de reinserção do reabilitado é visto por $\mathrm{G} 2$ como correto, procurando adequar o funcionário em atividades que o mesmo possa exercer.

No contexto organizacional, ao se tratar de um programa, plano e projeto, a sustentabilidade pode ser considerada como o objetivo e o desenvolvimento sustentável como o processo para se alcançá-lo (DIESENDORF, 2000; CLIFT, 2000), e uma restrição que deve ser considerada como um critério ao se avaliar as alternativas dentro de um processo quando se busca um objetivo desejado.

Afirmou que na empresa, os gestores recebem treinamento em relação a reintegração dos reabilitados, inclusive com supervisão do médico do trabalho no setor onde haverá a reintegração.

"Não vejo dificuldade em lidar com o trabalhador reabilitado. Vejo eles como trabalhadores normais, respeitando, claro, suas limitações" (G2, jan/2017).

Perspectivas em Gestão \& Conhecimento, João Pessoa, v. 8, n. 3, p. 40-66, set./dez. 2018. 
G2 diz que alguns reabilitados são bastante esforçados e querem trabalhar, tanto quanto os demais trabalhadores. Existe, geralmente, uma boa convivência entre todos.

Afirma ainda que não ocorreram mudanças dentro da empresa depois da reinserção do reabilitado. $O$ processo de reintegração é prática normal para ele. Além disso, se vê como um gestor justo, sem discriminar nenhum colaborador, seja reabilitado ou não. Quer ser lembrado como um bom gestor.

O relato do G2 é condizente com o tratamento que a empresa oferece para os reabilitados.

G3 acha que o reabilitado enxerga o gestor como um ponto de apoio, onde encontra força para sanar suas limitações. Alguns reabilitados, devido suas limitações, sentindo-se incapaz, acabaram por exercer má conduta na empresa, por exemplo, sair para fumar e demorar demais, fofocas, coisas que envenenam os demais colaboradores, etc.

Reabilitação profissional, para G3, é a oportunidade para que a pessoa consiga provar sua capacidade profissional. Diz ainda que nem todos os gestores estão preparados para lidar com um reabilitado, É necessário ter em mente que um reabilitado tem seus limites, e talvez não atenda o que um setor espera para um trabalho produtivo.

G3 afirma que o Programa de reabilitação Profissional prepara sim os reabilitados para o retorno a empresa, porém, na reabilitação deve-se também preparar quem lidera para que saiba lidar com a situação, e assim, não trate um reabilitado coo um incapaz.

O processo de reinserção do reabilitado é visto por G3 como uma quase obrigação, pois na maioria das empresas, sempre esperam alguém que proceda normalmente. Porém, na maioria das vezes os gestores não recebem treinamento para lidar com um reabilitado. Somente falam que é um reabilitado e que não pode efetuar certas atividades, ou seja, limitam mais ainda o funcionário.

\footnotetext{
"A maior dificuldade em lidar com o reabilitado é descobrir, em pouco tempo, o temperamento, a maneira de ver, pensar e sentir do mesmo perante os demais funcionários. E todos os reabilitados, dentro de seus limites, são tão produtivos quanto os demais" (G3, jan/2017).
}

G3 consegue identificar uma grande dificuldade na convivência dos reabilitados com os demais funcionários, pois os colegas pensam que fazem demais enquanto um reabilitado não consegue produzir o mesmo, e o ganho mensal é o mesmo. Dentro da empresa houveram mudanças após a reinserção de um reabilitado como a sensibilidade de alguns, a maneira de tratar o reabilitado, valorizando mais a vida.

G3 se vê como um gestor normal, esperando que mudanças de relacionamentos em aceitação a um reabilitado melhore, e através de treinamentos sobre o assunto, os gestores e chefes estarão mais preparados.

O gestor entrevistado acredita que o reabilitado o enxerga como um requisito para a Legislação vigente, e que muitos alegam que não estão em condição de trabalhar, mesmo que seja em outra atividade.

\footnotetext{
“Reabilitação profissional é a recuperação física e psíquica de uma pessoa para facilitar sua reintegração em sua atividade laboral, seja ela por acidente ou não, podendo desempenhar determinada função" (G4, fev/2017).
}

G4 afirma que os gestores não estão preparados para lidar com a reinserção do reabilitado, e que os reabilitados sem sempre dão seu máximo em sua atividade laboral. Afirma que o trabalhador reabilitado, muitas vezes, não se sente mais parte do todo da empresa e acha que a culpa é da empresa, visto que foi dentro da mesma que ele se acidentou e se machucou. 
Diz ainda que o Programa de Reabilitação Profissional prepara o reabilitado para a reinserção, porém é necessário que haja um acompanhamento constante. O programa é satisfatório, porém muitas vezes existe rejeição por parte do reabilitado.

Um exemplo é o caso de um trabalhador que retorna à empresa e é designado para permanecer em um local ou sala atendendo telefone ou acompanhando o movimento de entrada e saída de funcionários, quando não permanece totalmente ociosos sem nenhuma tarefa para realizar.

De acordo com Takahaschi (2010) as empresas dentro deste cenário ainda se sentem despreparadas para enfrentar o adoecimento de seus funcionários e de inseri-los dentro da empresa através de programas de reabilitação e dessa forma mantêm uma postura omissa e pouco contribuem para o processo de reinserção profissional. Portanto se faz necessário uma nova leitura do programa de reabilitação profissional. É preciso que a sociedade, os governos as entidades publicas e privadas assumam verdadeiramente suas responsabilidades e que através da coparticipação possam buscar um modelo "ideal" de Reabilitação Profissional, no qual prevaleça o sujeito enquanto cidadão, e lhe são assegurados o direito a eles inerente.

$\mathrm{Na}$ empresa de G4, existe um treinamento para os gestores, onde passam todo o processo do reabilitado, o porquê da reabilitação e como será feita a reinserção. A maior dificuldade é lidar com a auto estima do reabilitado.

Para o gestor, os reabilitados são tão produtivos quanto os demais trabalhadores, dentro das funções estabelecidas, conseguindo desempenhar suas funções, não afetando o sistema produtivo. Porém a convivência entre os reabilitados e demais trabalhadores apresenta algumas dificuldades, devido aos tipos de trabalho e salário, causando conflitos, uma vez que pela legislação vigente não se pode reduzir o salário, e por outro, o reabilitado trabalha proporcionalmente menos que os demais.

Esse gestor afirma que o reabilitado enxerga o gestor como um tirano, pois vai tirá-lo da sua zona de conforto, trazendo-o para a empresa e que o líder vai "tirar o couro" dele.

Disse ainda que houveram más condutas de reabilitados na empresa, principalmente por ter estabilidade e não concordava com o que estava fazendo. Dizia ainda "que não havia uma cama para ele repousar" ou "que não era obrigado a fazer o que a empresa quisesse"

"Reabilitação profissional consiste em resgatar o funcionário que está afastado do posto de trabalho na tentativa de aproveitar a mão de obra, trazendo o reabilitado para o convívio social" (G5, fev/2017).

Infelizmente, para G5, os gestores não estão preparados para lidar com os reabilitados, até mesmo por falta de informações, pelo achismo que ele é "aproveitador da situação", concordando com Poersch e Merlo (2017) que dizem que o retorno ao trabalho se faz, então, atravessado por estas vivências, particularizadas, confrontadas com os arranjos da organização que já não são mais os mesmos. Compondo equipes que não mais se constituem do mesmo modo e em relações e vínculos de trabalho que se fragilizaram face ao fomento dos modelos individualistas de gestão no trabalho, somados ainda ao longo período de afastamento do universo laboral.

Afirma ainda que o Programa do INSS é muito distante da realidade. O INSS propõe uma ação mas não entrega. $O$ discurso do INSS é um e no relatório vem outro. $O$ acompanhamento também é falho.

\footnotetext{
"Só tenho presenciado má vontade do reabilitado, eles já vêm rotulados e no modelo que é não funciona. A empresa dá treinamentos aos gestores, de como proceder no dia a dia com os reabilitados. Porém sente como dificuldade a resistência do reabilitado para aprender o novo, falta de disposição para aprender o que está sendo proposto" (G5, fev/2017).
} 
G5 afirma que os reabilitados não são produtivos como os demais trabalhadores, pois colocam objeção em tudo que é proposto. Além disso, existem dificuldades na convivência entre eles, porque quem está em rotina normal acaba tendo "medo" de manter uma aproximação do reabilitado, e em função dos que as outras pessoas vão falar.

De acordo com o gestor, houveram mudanças na empresa após a reinserção dos reabilitados. Os demais trabalhadores ficaram preocupados, meio ressabiados com atitudes e comportamentos da pessoa reabilitada.

Como gestor, ele pretende conseguir desenvolver essa pessoa para colocar em vida ativa, que volte a ser produtivo. Pretende ser um bom gestor, ser lembrado assim.

Para G6, o trabalhador reabilitado vê o gestor como alguém que terá que prestar contas sobre sua produção. Já passou por situações onde existiram má conduta dos reabilitados, por exemplo, tem os reabilitados que ficam mais de 1 hora fumando no banheiro, contaminando outros colegas com fofocas, etc.

Reabilitação profissional, para o gestor, é a oportunidade que o funcionário tem de exercer funções compatíveis com suas limitações e condições individuais. Dependendo do reabilitado, os gestores não estão preparados para lidar com a reinserção do mesmo, pois existem aqueles que o convívio é bem difícil.

\footnotetext{
"Sinceramente, para mim o Programa do INSS não funciona. Pois muitas vezes o trabalhador é empurrado de volta para a empresa sem condição de se adequar ao trabalho. O processo de reinserção do reabilitado deveria ser uma oportunidade e um recomeço para o mesmo. Mas não acontece assim" (G6, fev/2017).
}

Essa situação citada está de acordo com Ramos Junior (2016) dizendo que entende-se que o programa de reabilitação profissional atualmente disponibilizado pela Previdência Social necessita com urgência ser modernizado e reestruturado para atender às exigências das mudanças na esfera produtiva, o que representaria um enorme ganho para toda a sociedade, pois não podemos deixar a cargo exclusivo do empregador essa função, assim como também não podemos tomar com premissa que o empregado pretende burlar o sistema previdenciário para fazer jus a um beneficio permanente.

Quanto a treinamentos para o gestor receber o reabilitado, G6 diz que a empresa passa o que houve e como o trabalho agora precisa ser feito, frente as limitações do funcionário. É necessário que haja muito jogo de cintura para lidar com os reabilitados, pois eles voltam de um processo difícil em suas vidas.

Quando questionado sobre a produtividade dos reabilitados, G6 afirma que muitos são tão produtivos quantos os demais trabalhadores, são responsáveis e dedicados. Porém existem ainda dificuldades no relacionamento dos reabilitados com os demais trabalhadores. Na maioria das vezes preconceito devido as suas restrições laborais e salários.

Para a empresa as mudanças ocorridas com a reinserção dos reabilitados são boas, pois cumpre a legislação. E para o reabilitado a auto estima fica melhor. G6 se vê como alguém normal, que procura se colocar no lugar do outro, porém, sem esquecer de sua função dentro da empresa, que é liderar a produção, mas sempre tentando criar uma energia boa para o ambiente de trabalho.

De acordo com esse gestor, o reabilitado vê o chefe como alguém que pode ajudar ou prejudicar ele. Existem casos, sim, em que o reabilitado mostra má conduta, como exemplo, não ficar em seus postos de trabalho, conturbando o ambiente, não acatando as ordens, enfim, são colaboradores que não podem contar.

"Mesmo que todos tenham limitações, não são incapacitados de fazer, se houve um acidente/doença, e, não é tão grave, eles deveriam pensar que estão tendo 
uma nova chance de reconquistar ser espaço no ambiente de trabalho, e isso é reabilitação profissional" (G7, mar/2017).

Quando questionado se os gestores se encontram preparados para a reinserção do reabilitado, G7 diz que na maioria das vezes, sim, pelo menos tentam, porém que o Programa do INSS é insuficiente. Segundo o gestor, INSS não avalia corretamente se o reabilitado consegue realizar o que a empresa necessita, ocorrendo cobranças por resultados como se o reabilitado fosse uma pessoa com problemas físicos.

G7 diz ainda que o processo de reinserção de um reabilitado é complicado. Enquanto a pessoa está "boa", é útil, maravilha. A partir do momento em que adquire um problema, passa a ser "uma peça que tem que ser substituída", pois já não está apta a trabalhar. São dois lados da moeda.

Quanto aos treinamentos que os gestores recebem, G7 afirma que somente sabe o que devem cobrar do reabilitado. É necessário saber o que podemos e não podemos fazer. Porém só nos avisam que o reabilitado voltará e onde ele deverá trabalhar.

Como dificuldades em lidar com o reabilitado, G7 pontua que quando é necessário intervir e cobrar disciplina, conduta ou postura, o reabilitado alega desrespeito, agride com palavras e ainda responde que faz além de suas limitações. Usa suas limitações como desculpa para não trabalhar normalmente.

\footnotetext{
"Há muito reabilitados que são participativos e esforçados, mesmo não podendo exercer as antigas funções. Ajudam de alguma forma o processo produtivo. $\mathrm{Na}$ minha opinião, o reabilitado cria uma barreira para ele mesmo, o que dificulta a comunicação e a interação entre os demais colegas" (G7, mar/2017).
}

G7 se vê como um líder que pode ajudar a fazer o ambiente de trabalho um lugar bom para se viver e se realizar. Muito focado para atingir as metas estipuladas por ele, precisa trabalhar o lado emocional e parar de levar os problemas da empresa para casa.

O G8 não respondeu o questionário, mas disse que afastou apenas um reabilitado por acidente e infelizmente não teve postos compatíveis para ele dentro da empresa. O programa do INSS nesse caso não funcionou porque o reabilitado fez um curso de qualificação para sucro alcooleiro e não tem como manter ele, já que a empresa não trabalha com isso, uma vez que seu setor de atuação era embalagem de vidro.

O G9 também não respondeu o questionário e diz não ter nenhum reabilitado na empresa que tenha essas condições, doença ou acidente de trabalho. Só trabalham com deficientes e aprendizes. Assim, infelizmente, não pode nos ajudar na pesquisa.

A G10 afirmou não haver disponibilidade em nenhum desses casos (nem entrevista ao vivo, nem por telefone e nem por e-mail) de participar da pesquisa. A Diretora, deixou claro que não há nenhum caso de reabilitado na empresa e nem disponibilidade de tempo para colaborar com a pesquisa.

\section{DISCUSSÕES}

Esta pesquisa analisou a reintegração de funcionários no ambiente de trabalho, que passaram pelo programa de Reabilitação Profissional. Pode-se observar que a maior parte dos reabilitados não participaram do Programa de Reabilitação, e, mesmo entre os que participaram, não houve acompanhamento, nem procedimento adequado para uma recuperação eficaz. A maioria dos reabilitados não retornou às suas atividades, e quando retornou não tinham a mesma eficiência produtiva.

Perspectivas em Gestão \& Conhecimento, João Pessoa, v. 8, n. 3, p. 40-66, set./dez. 2018. 
De 10 trabalhadores entrevistados, 2 foram reinseridos na empresa de vínculo, exercem as mesmas funções de antes do acidente e/ou doença, porém apenas 1 deles foi reinserido após ter participado do programa de reabilitação profissional do INSS; 3 ainda estão afastados pelo INSS, sendo que para apenas 1 deles foi oferecido ajuda no programa de reabilitação profissional, onde o INSS participa ajudando com o transporte; 3 foram desligados das empresas onde trabalhavam, os 3 participaram do programa de reabilitação profissional do INSS, sendo que 1 não conseguiu que a empresa desse baixa em sua carteira e hoje brigam na justiça, e 2 pediram demissão não aguentando mais tanta pressão e descaso e partiram em busca de novas possibilidades.

De acordo com o motivo do afastamento, em primeiro lugar verificou-se vários acidentes de trabalho seguido de doenças causadas por esforço demasiado. Este fato acontece devido à falta de prevenção no ambiente laboral, incluindo falta de material pessoal e profissional.

Além disso, através do Programa de Reabilitação Profissional, a pesquisa mostrou a necessidade de uma reforma no Programa de Reabilitação, exigindo informação sobre a importância do programa, um treinamento melhor e intervenção por parte das empresas, agindo, assim, na causa e não no efeito, melhorando a qualidade de vida desses atores sociais através de uma melhor política pública.

Quantos aos gestores, todos sem exceção dizem que o processo de reinserção do reabilitado deveria ser uma oportunidade para o trabalhador e não um obstáculo, como a maioria dos reabilitados enxergam. Porém, quando perguntado sobre sua percepção sobre o se o programa de reabilitação profissional atual funciona apenas 3 deles disseram estar satisfeitos com os resultados do programa.

Através da reabilitação é possível pegar o lado humano do trabalhador, o empoderamento, dar voz ativa a ele, devolver a tomada de consciência, diminuir suas angustias e incapacidades, acabando com a opressão, assédio moral, oferecendo bem-estar e qualidade de vida. Neste aspecto da reabilitação profissional, cuidar é considerar a importância da construção de projetos de vida, significativos para cada reabilitado, como eixo central do tratamento.

Quadro 5: Sintetização dos resultados observados na pesquisa - Reabilitados

\begin{tabular}{|l|l|}
\hline \multicolumn{1}{|c|}{ Categoria de Análise } & \multicolumn{1}{|c|}{ Percepção dos entrevistados - Reabilitados } \\
\hline Motivo do afastamento & $\begin{array}{l}\text { Doença por esforço demasiado } \\
\text { Acidente de trabalho }\end{array}$ \\
\hline Programa de Reabilitação do INSS & $\begin{array}{l}\text { Treinamento mais humanizado e intervenção por parte } \\
\text { das empresas }\end{array}$ \\
\hline Reabilitação Profissional & $\begin{array}{l}\text { Considerar a importância da construção de projetos de } \\
\text { vida }\end{array}$ \\
\hline Condições de trabalho após reabilitação & $\begin{array}{l}\text { Não conseguiram voltar as suas atividades anteriores, não } \\
\text { conseguiram ser "encaixados" novamente no trabalho, } \\
\text { incapacidade, limitação }\end{array}$ \\
\hline Significado de Trabalho & Dignidade. Vida \\
\hline Maiores barreiras enfrentadas & Dores físicas, emocional abalado, sentimento de injustiça \\
\hline
\end{tabular}

Fonte: Elaborado pela autora, com base na pesquisa (2017)

Quadro 6: Sintetização dos resultados observados na pesquisa - Gestores

\begin{tabular}{|c|c|}
\hline Categoria de Análise & Percepção dos entrevistados - Gestores \\
\hline Motivo do afastamento & $\begin{array}{l}\text { Doenças causadas por esforço demasiado } \\
\text { Acidente de trabalho }\end{array}$ \\
\hline Programa de Reabilitação do INSS & $\begin{array}{l}\text { Processo de reinserção do reabilitado deveria ser uma } \\
\text { oportunidade para o trabalhador e não um obstáculo }\end{array}$ \\
\hline Reabilitação Profissional & $\begin{array}{l}\text { Mostra a capacidade que esses trabalhadores apresentam } \\
\text { exercendo suas funções e sendo tão produtivos quanto os } \\
\text { demais colaboradores }\end{array}$ \\
\hline Condições de trabalho após reabilitação & Melhoria nas condições oferecidas \\
\hline
\end{tabular}

Perspectivas em Gestão \& Conhecimento, João Pessoa, v. 8, n. 3, p. 40-66, set./dez. 2018. 
\begin{tabular}{l|l} 
Como são como gestores & Sem exceção, se veem como bons profissionais
\end{tabular}

Fonte: Elaborado pela autora, com base na pesquisa, 2017

Nos casos analisados percebe-se que não existiu acompanhamento por parte do INSS ou das empresas no período de afastamento dos funcionários. De acordo com a legislação, deve haver acompanhamento de um médico, fisioterapeuta, psicólogo e assistente social.

Infelizmente o que acontece na pratica é que o trabalhador reabilitado, por imposição do INSS que cessa seu auxílio-doença, precisa voltar para a empresa, mesmo sem ter condições clinicas de realizar qualquer atividade laboral. A consequência é o agravamento da doença, sem contar as sequelas físicas e emocionais.

Em alguns casos tratam o reabilitado como um funcionário normal e até mesmo produtivo igual aos demais. Em outros casos, o gestor afirma que o reabilitado aproveita essa estabilidade e começa a fazer corpo mole dentro da empresa, a contaminar seus colegas com fofocas, etc., ou então, não há postos compatíveis para o reabilitado e ele tem que voltar para a mesma função.

Muitas vezes a empresa prefere deixar o reabilitado afastado por anos e anos ao invés de colocá-lo novamente dentro da empresa em um posto compatível, alegando não haver espaço em postos compatíveis.

Assim foi possível detectar a existência de um desacordo desses atores sociais do estudo com o programa de reabilitação profissional.

Para que ocorra uma efetiva reabilitação, é importante a reinserção da pessoa na sociedade. Quando a própria pessoa acredita que é incapaz ou impotente frente à dinâmica de sua vida, há o surgimento de um estado de inércia e diminuição de sua condição para o enfrentamento das dificuldades vividas, situação que pode ser modificada à medida que o apoio da rede social se amplia.

A dor, a falta de um posto de trabalho compatível com as doenças, o emocional abalado e o sentimento de incapacidade profissional são as maiores barreiras enfrentadas por esses reabilitados. Enquanto que os gestores, todos sem exceção, mostraram que se veem como bons profissionais e almejam para o futuro uma vida estabilizada e tranquila, com grande crescimento profissional.

\section{CONSIDERAÇÕES FINAIS}

Há necessidade brasileira, urgente, de implantação de uma política de prevenção de acidente de trabalho e uma fiscalização efetiva das empresas para com o trabalhador que chegue numa situação de doença ou acidente de trabalho, para que não permaneça incapacitado e que depois consiga voltar para a mesma empresa ou para o mercado de trabalho. Se houvesse uma fiscalização preventiva todos poderiam ficar satisfeitos. $O$ trabalhador seria cuidado preventivamente, o setor público ganharia porque o INSS poderia economizar o benefício gasto por incapacidade desse segurado e a empresa também ganharia porque permaneceria com o mesmo funcionário e não precisaria repor mão de obra.

A reabilitação profissional é um serviço onde o objetivo é recuperar a condição de trabalho desse segurado a fim de exercer uma nova atividade profissional, garantindo assim o bem-estar físico, mental e social. Além disso, o reabilitado se torna satisfeito, mantém o emprego, alimenta a autoestima, a criatividade e o conhecimento.

Porém os trabalhadores reabilitados desconhecem para que serve o programa de reabilitação profissional do INSS.

Embora a ideia do programa seja boa, infelizmente não existe uma efetividade nesse processo de reabilitação profissional, pois, o reabilitado ao ser submetido ao programa ele não encontra no mercado de trabalho uma nova oportunidade de emprego, visto que, a atividade que ele exerce não consegue encontrar muitas opções que estejam de acordo com sua condição atual.

Perspectivas em Gestão \& Conhecimento, João Pessoa, v. 8, n. 3, p. 40-66, set./dez. 2018. 
Quanto às empresas, os discursos entre os gestores, muitas vezes, são camuflados os conflitos vividos, nos quais inclui a diferença e a indiferença ao sofrimento do outro e um tratamento digno na empresa, sendo o principal a produtividade

As organizações por obrigação do INSS recebem esse trabalhador que é submetido a um "subemprego" ficando muitas vezes ocioso apenas para cumprir a legislação. Apesar de existir no Brasil a garantia constitucional de bem-estar aos trabalhadores, a realidade ainda é muito distante, uma vez que o sistema previdenciário atual tem por objetivo a obtenção de renda e capital e não a aplicação ou construção de um programa social efetivo.

Na verdade, observou-se que a realidade vivida por esses reabilitados não é condizente com a legislação.

Como alternativa resta garantir a sobrevivência por meio de trabalho informal, a esperança da prorrogação do benefício previdenciário ou quem sabe conseguir a invalidez pelo INSS, o que não soa como um algo injusto e sim como um direito à cidadania. Fato que mostra uma enorme distância entre o sugerido por lei e sua realização.

\section{REFERÊNCIAS}

BARDIN, Laurence. Análise de conteúdo. 5. ed. Lisboa: Edições 70, 2011.

BARRETO, Margarida. Violência, Saúde e Trabalho: uma jornada de humilhações. Editora: PUC São Paulo Educ. São Paulo, 2013. 233 pp.

BRASIL. Ministério da Previdência e Assistência Social. Previdência Social, 2001. Disponível em: http://www.previdenciasocial.gov.br. Acesso em: 15 out. 2015.

CAMARGO, Brigido Vizeu. ALCESTE: um programa informático de análise quantitativa de dados textuais. In: MOREIRA, Antônia Silva Paredes et al. (Orgs). Perspectivas teórico-metodológicas em representações sociais. João Pessoa-PB: Editora Universitária, 2005.

CAMARGO, Brigido Vizeu; JUSTO, Ana Maria. Tutorial para uso do software de análise textual IRAMUTEQ. Florianópolis-SC: Universidade Federal de Santa Catarina, 2013.

CESTARI, Elisabete; CARLOTTO, Mary Sandra. Reabilitação profissional: o que pensa o trabalhador sobre sua reinserção. Estudos e pesquisas em psicologia. Reabilitação Profissional, Rio de Janeiro, v. 12, n. 1, p. 93-115, 2012.

CLIFT, Roland. Forum on sustainability. Clean Products and Processes, v. 2, n. 1, pp. 67, 2000.

DIESENDORF, Mark. Sustainabilkity and Sustainable Development. In Dunphy, D.; Benveniste, J.; Griffiths, A. and Sutton, P (Eds). Sustainability: The corporate Challenge of the 21st Century, Sidney: Allen \& Unwin, chapter 2, pp. 19-37, 2000.

GIL, Antonio Carlos. Como elaborar projetos de pesquisa. 4. ed. São Paulo: Atlas, 2009.

JACQUES, Maria da Graça Correa; CODO, Wanderley. Saúde mental \& trabalho. Petrópolis: Vozes, leituras, 2002, 2a ed. 
MASSONI, Tulio de Oliveira. Os Desafios do Trabalhador em Face da (Indevida) Alta Previdenciária. Rev. Bras. De Previdência: Atuária, Contabilidade e Direito Previdenciário - Universidade Federal de São Paulo, 1. Ed., Nov/2012.

MILLER, Jody; GLASSNER, Barry. The inside and the outside: Finding realities in interviews. In Silverman D. Qualitative Research: Theory, Methods and Practice (2. ed) London: Sage Publications, 2011, p.125-39

OLIVEIRA, Luciel Henrique de; SILVA, Poliana Maria Bernardo; PALAZI, Edgar Jorge. Inserção de portadores de deficiências nas empresas: um estudo exploratório em Minas Gerais. In: Seminários em administração FEA USP, 10, 2007, São Paulo. Anais do IV Seminário Internacional. Sociedade Inclusiva. São Paulo: USP, 2007. p. 1-14.

OIT. Organização Internacional do Trabalho. Portal Corporativo. Escritório no Brasil. Disponível em http://www.oitbrasil.org.br. Acesso em 02/08/2018.

POERCH, Ana Luiza; MERLO, Álvaro Roberto Crespo. Reabilitação profissional e retorno ao trabalho: uma aposta de intervenção. Psicologia Social, v. 29, Belo Horizonte, 2017.

RAMOS, Marcia Ziebell; TITTONI, Jaqueline; NARDI, Henrique Caetano. A experiência de afastamento do trabalho por adoecimento vivenciada como processo de ruptura ou continuidade nos modos de viver. Caderno de Psicologia Social do Trabalho, 2008.

ROSSI, Daniela; TAKAHASHI, Mara Alice Batista Conti. Reabilitação Profissional Pública, um Direito do Cidadão. São Paulo-SP, 2007.

SANTOS, Viviane Silva. Reabilitação Profissional X Empresa: corresponsabilidade necessária. Disponível em: http://www.ieprev.com.br/conteudo/id/15908/t/direito-previdenciario-reabilitacaoprofissional-x-empresa-co-responsabilidade-necessaria. Acesso em: 01 ago. 2015.

SEIDL, Eliane Maria Fleury; ZANNON, Célia Maria Lana da Costa. Qualidade de vida e saúde: aspectos conceituais e metodológicos. Cad. Saúde Pública, v. 20, n. 2, mar./abr. 2004.

TAKAHASHI, Mara Alice Batista Conti; SIMONELLI, Angela Paula; SOUSA, Helder do Prado; MENDES, Renata Wey Berti; ALVARENGA, Maria Valéria de Andrade. Programa de Reabilitação Profissional para Trabalhadores com Incapacidades por LER/DORT: relato de experiência do Cerest-Piracicaba. Revista Saúde Ocupacional, São Paulo, p. 100-111, 2010.

YIN, Robert K. Estudo de caso: planejamento e métodos. 2.ed. Porto Alegre: Bookman, 2010.

Artigo recebido em 26/05/2017 e aceito para publicação em 30/11/2018 